\title{
The bittersweet fruits of industrialization in rural China: The cost of environment and the benefit from off-farm employment
}

\author{
Ying LIU ${ }^{\mathrm{a}, *}$, Jikun HUANG ${ }^{\mathrm{b}, 1}$, Precious ZIKHALI ${ }^{\mathrm{c}}$ \\ a School of Economics and Management, Beihang University, Beijing 100191, China \\ b Center for Chinese Agricultural Policy (CCAP), Institute of Geographical Sciences and Natural Resources Research, Chinese Academy of Sciences, Beijing 100101, China \\ c Southern Africa Regional Office, International Water Management Institute, Private Bag X813, Silverton, Pretoria 0127, South Africa
}

\section{A R T I C L E I N F O}

\section{Article history:}

Received 30 April 2015

Received in revised form 11 November 2015

Accepted 11 November 2015

Available online 17 November 2015

\section{JEL classification:}

Q56

\section{Keywords:}

Industrial pollution

Off-farm employment

Rural China

\begin{abstract}
A B S T R A C T
While it is widely accepted that industrialization has brought both environmental pollution and economic growth in rural areas of China, very little is known about whether the negative effects of industrial pollution on rural residents have been proportionally offset by positive effects due to improvements in off-farm income. This paper improves our understanding of these tradeoffs by conducting an empirical analysis based on a set of nationwide panel data collected in 2008 and 2012 and covering five provinces, 101 villages, and 2020 households. Evidence is found to suggest that it is not always the case that rural households that are affected by pollution reap the off-farm employment benefits associated with industrialization. Specifically, although industrial pollution incidence is found to be positively related with the level of local off-farm employment, this relationship is statistically insignificant when migrant labor is included. It can be explained as areas that less economically benefited from industrialization tent to have more labors migrated out and the average annual wage income of one migrant labor is much higher than that of local off-farm labor.
\end{abstract}

(c) 2015 Elsevier Inc. All rights reserved.

\section{Introduction}

The rapid industrialization in China has been accompanied by environmental, health, and social problems. The economy-wide policy reforms designed to promote growth and liberalization have had little regard for their environmental consequences (World Bank, 2007). Industrial pollution, especially air and water pollution, are a major source of morbidity and mortality in China (Zhang et al., 2010; Ebenstein, 2012). The government receives more than 700,000 in 2010 complaints related to environmental problems from the public through letters and calls (xin fang), which was 12 times more than that in 1995 (Ministry of Environmental Protection, MEP, 1995, 2010). The economic cost of environmental degradation to China was estimated to range from eight to 12\% of its GDP between 2000 and 2006 (World Bank, 2007).

Compared to their urban counterparts, rural residents tend to be more adversely affected by the process of rural industrialization. Rural industrialization could be traced back to the antetype of township and village enterprises, which were promoted by the government in the late 1970s. The aim was to spur rural economic growth and ease problems of overcrowding and urban unemployment by creating employment opportunities for the surplus labor in agriculture. In general, rural residents, who accounted for nearly 50\% of total population, have been found to suffer more environmental pollution from industry after controlling for other socioeconomic factors (Ma, 2010). This is partly due to differences in the stringency of environmental policies between rural and

\footnotetext{
* Corresponding author. Tel.: + 8613552755872.

E-mail addresses: Liuying@buaa.edu.cn (Y. Liu), jkhuang.ccap@igsnrr.ac.cn (J. Huang), prehgabadela@gmail.com (P. Zikhali).

1 Tel.: + 861064889440
} 
urban areas (Engardio, 2009; Su \& Ma, 2006). Furthermore, enforcing environmental regulations tends to be harder in rural areas (Wang, Webber, Finlayson, \& Barnett, 2008), mainly due to the low densities in rural industries and the insufficiency of environmental monitoring (Swanson, Kuhn, \& Xu, 2001; Tilt, 2007; Wang, 2006).

Like a coin has two sides, industrialization has undoubtedly had an important and well-documented role in dramatic changes in rural labor market and rural economic growth. The proportion of net income from agriculture steadily shrinks to $1 / 3$ of total income (China rural statistical yearbook, 2013), and off-farm income has become the most disequalizing component of rural household income (Fang \& Rizzo, 2011; Khan, Griffin, Riskin, \& Zhao, 1992; Wang, Smyth, \& NG, 2009). First, rural industrialization succeeded in stimulating economic activity and raising income levels in rural areas (Rizwanul \& Jin, 1994). Second, migrant income also contributed much to total off-farm income. A large number of rural residents have been moving from the countryside to the city, from underdeveloped economic areas to developed areas. In 2013, 19\% rural labor engaged in off-farm employment in local town and 31\% labor in rural areas migrated out of local town (National Bureau of Statistics of the People's Republic of China (NBSPRC), 2014).

However, the relationship between income growth and industrial pollution in rural China, the bitter and sweet fruits of industrialization, is a little complicated. Empirical studies often suggest that the relationship is not straight forward; specifically, pollution rises at early stages of economic development, and this trend is reversed in the later stages of development as growth becomes more environmentally friendly. That is to say the estimating results of the relationship depend upon the stage of economic growth.

Furthermore, in the context of China's migration phenomenon, the relationship between industrial pollution and level of total off-farm income, in which migrant income is included, is more confusing. Rural households enjoy economic benefits from industrialization both in local and urban areas, while rural environment is only associated with local industry. The impact of local industrialization on migrant employment might be confusing. On the one hand, areas that less economically benefited from industrialization tent to have more labors migrated to urban areas to seek higher income. While on the other hand, areas that suffering serious industrial pollution might also give rise to migration to less-polluted areas.

The primary objective of this paper is to examine whether the negative effects of industrial pollution on rural residents have been proportionally offset by positive effects due to improvements in off-farm income. While it is widely supposed that industrialization has brought both environmental pollution and economic growth in rural areas of China, very limited empirical research has been conducted to investigate whether the residents that are adversely affected by the environmental consequences of industrialization in rural China have been proportionally compensated by improvements in off-farm income. Possibly due to lack of data on rural industrial pollution, there has been no quantitative research on the relationship between industrial pollution and local off-farm employment in rural China. This paper fills this gap. It measures the prevalence of industrial pollution in a highly comprehensive way based on the households' perceptions on industrial pollution. A data set on 2020 households from five provinces in rural China is used to statistically and econometrically analyze the relationship between industrial pollution and off-farm incomes in rural China. The findings of the paper will have significant policy implications not only on balance between environmental conditions and economic development in rural China but also on ensuring sustainability of China's economic growth.

The rest of the paper is organized as follows: Literature review is offered in the next section, followed by a discussion of the data collected by the authors in 2008 and 2012. Sections 4 and 5 provide a statistical analysis on the intensity of industrial pollution and villagers' off-farm employment, respectively. This is followed by a brief outline of the econometric methodology used in the analysis, and Section 7 presents the results and discussions. Section 8 concludes the paper and offers policy recommendations.

\section{Literature review}

The relationship between industrial pollution and income has long been debated. The long-term relationship between pollution and income has been conceptually captured through the environmental Kuznets curve (EKC), which posits that pollution is an inverted-U shape function of income per capita. Intuitively, this means environmental degradation (pollution) rises as a country goes through early stages of economic development, and this trend is reversed in the later stages of development as growth becomes more environmentally friendly. In the case of China, different studies estimating an EKC often generate different results depending upon type of pollutant used and how it is measured (Diao, Zeng, Tam, \& Tam, 2009; Du, Wei, \& Cai, 2012; Henri, Cees, \& Zhou, 2004; Jalil \& Mahmud, 2009; Liu, Heilig, Chen, \& Heino, 2007; Shen, 2006; Song, Zheng, \& Tong, 2008; Yang, Yang, \& Sheng, 2011). While interesting, measuring the prevalence of industrial pollution in a highly comprehensive way is a challenge. This partly explains the mixed results revealed in existing studies on the EKC in China, as in other countries.

In recent years, research on environmental inequality in China has been growing. The main difference between this kind of research and that on EKC is that the later focuses on the national level and examines the long-term relationship between pollution and income, whereas environmental inequality research typically focuses on the manner in which the quality (e.g., pollution) of the environment is distributed across different population groups and/or locations in the country. Research on environmental inequality sheds light on who bears the environmental burden.

The main research question associated with environmental inequality is whether the rich and poor bear the environmental burden disproportionately differently. Evidence on this is mixed. Ma (2010) suggests that people who benefited more, economically, from increased industrial production tend to suffer the most environmentally. On the contrary, some researchers argue that China's poor are disproportionately affected by environmental burdens (World Bank's, 2007; Tang et al., 2008). Brajer, 
Mead, and Xiao (2010) found that the Gini coefficient increased when Chinese urban income inequality was adjusted for air environmental equity, demonstrating that poor urban residents are more infected by air pollution.

Besides income, there are several other factors that contribute toward environmental inequality in China. Location or geography matters: research on Hebei province found that polluting firms are more likely to set up in border counties than in interior ones due to less stringent environmental protection in border counties, because of the transboundary pollution problems (Duvivier \& Xiong, 2013). Lu and Zhong (2009) found that cancer villages tend to cluster along the major rivers and their branches with high population density, which also are the prime location choices for industries that require cheap water, labor, and transportation. In an analysis of the locations and emissions of polluting facilities in China's Jiangsu province, Schoolman and Ma (2012) find that townships with a higher percentage of rural migrants are more likely to be exposed to high levels of air and water pollution.

The mixed evidence on the relationship between pollution and income suggests a need to further examine this relationship in China, especially in rural areas. The focus on rural residents is of policy significance given that residents of rural China tend to be of a lower economic and social status compared to their urban counterparts. Environmental justice research in the United States shows that the poor and minorities are more likely to live in close proximity to environmental hazards (Apelberg, Buckley, \& White, 2005; Downey, 2006; Mohai \& Saha, 2006). While the story does not fit well in the Chinese context because China's population is overwhelmingly dominated by Han people (91.53\%), it fits well in the context of residents of rural areas who have historically been the low status group. Except for a case study of cancer villages from Lu and Zhong (2009), which argued that more economically developed areas have more cancer villages, none of the existing studies have assessed the relationship between industrial pollution and off-farm incomes in rural China. This paper does precisely that.

\section{Sampling and data}

The data used in this study are a subset of a data set that was collected during two waves of nationwide surveys carried out in early 2008 and early 2012. The surveys have been conducted through direct interviews of village leaders and heads of households, which come from a nationally representative sample of 101 rural villages in five provinces.

In the first wave in 2008, we conducted a survey using a stratified and random sampling framework. First, five sample provinces were randomly selected from each of China's major agro-ecological zones, which is Jiangsu (represents the rich, coastal areas in the east-south of China), Sichuan (represents the west-south of China), Shannxi (represents the west-north of China), Jilin (represents the east-north of China), and Hebei (represents the north of China). Second, to accurately reflect varying income distributions within each province, one county was randomly selected within each income quintile for the province, as measured by the gross value of industrial output. In total, there were 25 countries surveyed. We followed similar stratified random sampling procedures to select townships from each county and two villages from each township. Finally, the team used village rosters to randomly choose 20 households in each village. ${ }^{2}$ In total, five provinces, 25 counties, 50 towns, 101 villages (one extra village was accidentally involved in our survey), and 2020 households were included in the survey.

In each village, we conducted two separate surveys: a village survey and a household survey. For the village survey, we gathered information on the village from the village leader (or accountant). The information is on the population, land area, as well as the distance from village committee to township seat. The household survey captured information on household and individual characteristics, for example, the education level and perceptions of industrial pollution of the respondents and participation in off-farm employment of all the family members. The survey was conducted in early 2008 , and thus the information on household perceptions of industrial pollution is from 2008; the other information on individual and village characteristics, on the other hand, is from 2007.

The use of household survey data allows for the measurement of the intensity or prevalence of industrial pollution in a comprehensive way. Focusing on different pollutants separately presents an incomplete picture of the relationship between pollution and income (Brajer, Mead, \& Xiao, 2011). This paper measures the prevalence of industrial pollution in a comprehensive way by asking households to report whether they are suffering industrial pollution or not, whether air, water, or other pollution in their daily life. Households were asked, "Whether your family has been affected by any industrial pollution," and if yes "please list the names or types of polluting enterprises that affect your family." Although such a measurement of pollution intensity is more subjective than the traditional pollution index, it enables us to analysis the pollution problem in a broad and practical way.

Detailed information was collected on off-farm employment of each person within each household. Off-farm employment defined in this paper included both wage earners and self-employed ${ }^{3}$ engaged in industry and service sector (including public services), and sideline activities are also included. For each member in a household, we asked about their off-farm experience in 2007. Once a wageearning or a self-employment was identified, we asked the type of work, location, and estimated days engaged in wage-earning or self-employment, and also the annual wage income for wage earners, payment in kind also converted into money.

In the second wave survey of 2012, we went back to the same villages that were surveyed in 2008 . We were able to find and resurvey 1726 households among the 2020 households surveyed in 2008. The other 294 households could not be resurveyed as they either moved out of the village or could not engage in our survey for personal reasons. We randomly selected and included

\footnotetext{
${ }^{2}$ Households wholly migrated out of the village would not be involved in the survey, as they neither affected by local pollution, nor have any relationships with local economy.

${ }^{3}$ Self-employed business is in general regarded as privately owned, profit seeking business known as ge ti hu (individual business), or larger si ying qi ye (private enterprise). These businesses are predominantly engaged in industry and service sector (for example retailing, catering, serviced, repairs, construction, transport, light manufacturing).
} 
294 new households in the 2012 survey to ensure that there were still 2020. As in 2008, household and village leaders (or accountants) were interviewed in each village to get the panel data.

During the survey in 2012, employment information on local enterprises was also collected. We collected information on two kinds of enterprises. First, we asked the village leaders (or accountant) about whether there is any enterprise (with at least three employees, family members are excluded) within the village's administrative region. If the answer was yes, further information was asked about the four biggest enterprises, including the name of the enterprise and the employment information. We did not ask village leaders to only report the polluting enterprise and then focus the survey on polluting enterprises because the village leaders' personal judgment about whether the enterprise is polluting might not be objective, given the potential intimate relationships between village leaders and the enterprises. Of all the 101 sampling villages, 58 villages reported to have enterprises, in which 17 villages reported to have more than four enterprises. In total, 158 enterprises were investigated, which could represent most of the enterprises in the sampling area. Second, we also asked the village leaders (or accountant) about whether there is any polluting enterprise outside of the village's administrative region; 17 enterprises were reported.

\section{Measuring intensity of industrial pollution}

Households' perceptions could be aggregated into village level to compose a new variable of "intensity of industrial pollution," to identify the percentage of households affected by pollution in the village. Of all the households affected by pollution, $12 \%$ and $24 \%$ of households reported more than one pollution sources in 2008 and 2012, respectively. The perception of industrial pollution of each household is usually different from each other, even if they are from the same village. This is reasonable considering the non-uniform distribution of industrial pollution in the village. If we simply convert the households' reply into a yes or no variable, which indicates whether the household is affected by industrial pollution or not, the household data could then be aggregated into village level to compose a new variable of "intensity of industrial pollution," to identify the percentage of households affected by pollution in the village, i.e., the prevalence of industrial pollution. Such a comprehensive measurement of pollution intensity would enable us to analysis the pollution problem in a broad and practical way.

A natural concern related to the research design is that the prevalence of industrial pollution reported by villagers might be correlated with their personal characters. For example, villagers with higher income or education levels could be more informed about environmental pollution (Dunlap \& Mertig, 1997; Edmonds, 1998). If this is the case, the reported industrial pollution intensity is not an objective index to measure industrial pollution. That is, households with higher income or education levels might report higher levels of industrial pollution intensity, other things being equal. While in contrast to the common view that poor individuals and communities worry less about environmental problems, a more recent study focused on rural China found that despite economic conditions below the national and provincial averages, most informants were keenly aware of and concerned about the environmental risks posed by their local enterprises, although the perceived severity of risk from industrial pollution by different occupational groups was hardly uniform (Tilt, 2006). Moreover, statistical correlation tests of education levels and perceptions of industrial pollution found a correlation coefficient of 0.0347 , which means education does not have a systematic relationship with household's' perception of industrial pollution. We thus believe the pollution intensity reported by villagers is a reliable indication of the intensity or prevalence of industrial pollution.

Industrial pollution is revealed to be on the rise in rural China. The prevalence of industrial pollution in 2008 and 2012 is presented in Table 1 . The proportion of households affected by industrial pollution was $10.7 \%$ in 2008 , and this figure increased to $17.9 \%$ in 2012. The difference between these 2 years was found to be statistically significant at one percent level of significance. We further classify the polluting enterprises into two categories: pollution-intensive industries and non-pollution-intensive industries, ${ }^{4}$ according to the information of the types of the polluting factories. Both pollution from pollution intensive and nonpollution intensive industry increased between 2008 and 2012.

\section{Off-farm employment and the intensity of industrial pollution}

In this section, we investigate the off-farm employment and its likely relationship with the prevalence of industrial pollution. To do this, we use the amount of time spent on off-farm employment or off-farm wage income of the wage earners to measure the development of off-farm employment. There are two reasons behind examining only the income of wage earners but excluding the income from self-employment. First, net revenue of the current year might not represent the entrepreneur's actual income level, as the cash flow is hardly uniformly distributed in each year, in addition to it being difficult for the business owner to say the exact annual net revenue. Second, although self-employment expanded quickly in the 1980s and 1990s, it was falling by the 2000s. At the same time, wage earning increased steadily and became the primary type of off-farm employment in rural China (Jia, Xiang, \& Huang, 2013; Wang, Huang, Zhang, \& Rozelle, 2011). According to our survey, the relative size of wage earners' share on total off-farm employment time was $80 \%$ and $78 \%$ in 2008 and 2012, respectively. We believe wage income of wage earners could represent the majority of the development level of off-farm employment.

Off-farm employment became a more important means for rural residents to diversify their income in China, as both the amount of off-farm employment time and off-farm wage income increased between 2008 and 2012. As shown in Table 2, annual

\footnotetext{
${ }^{4}$ Pollution intensive industries included mining (the majority of which is coal mining), chemical raw material and chemical, power plant, paper making, cement and metal material. Non-pollution intensive industry included building and decorative materials, brewing, medicine, textile and tannery, and agricultural products processing.
} 
Table 1

Percentages of households being polluted by industry in rural China in 2008 and 2012

\begin{tabular}{|c|c|c|c|c|}
\hline & \multirow[b]{2}{*}{ Sample } & \multicolumn{3}{|c|}{ Percentages of households affected by industrial pollution } \\
\hline & & Total $^{\mathrm{a}}$ & Pollution intensive industry & Non-pollution intensive industry \\
\hline 2008 & 2020 & 10.7 & 6.9 & 4.9 \\
\hline 2012 & 2020 & 17.9 & 11.8 & 8.2 \\
\hline
\end{tabular}

Source: Authors' 2008 and 2012 survey.

a The value of "total" is lower than the summation of "pollution intensive industry" and "non-pollution intensive industry" because if the village suffers from both pollution intensive and non-pollution intensive industrial pollution, it would be only counted as one occurrence.

per capita off-farm employment time increased from 80 to 83 days from 2008 to 2012. This is consistent with previous studies (Jia et al., 2013; Knight, Deng, \& Li, 2011; Wang et al., 2011). At the same time, annual per capita off-farm wage income grew even faster, which increased from 2999 to 5444 yuan between 2008 and 2012, which were put into real 2008 yuan terms using the Consumer Price Index from the China Statistical Yearbook (China National Statistical Bureau, 2013).

Further breakdown demonstrates that, although migration is the primary type of off-farm employment in 2008, local employment increased dramatically and became the dominant component in 2012. We disaggregated off-farm employment into local and migrant employment according to the location. Migrants are defined as labor moving out of town, which is consistent with the definition from the China National Bureau of Statistics. Table 2 shows that local off-farm employment is rose while migrant employment fell. In particular, the amount of annual local off-farm employment time was 32 days per capita in 2008, and this figure increased to 46 in 2012, becoming the dominant component. On the contrary, the amount of migrant off-farm employment time decreased from 48 days per capita (80-32) in 2008 to 37 days per capita (83-46) in 2012.

Regarding wage income, the survey results show that the booming growth of off-farm wage income was mainly driven by the well performance of local wage earners. Specifically, annual wage income from local town was 884 yuan per capita in 2008, and this figure increased to 2519 yuan per capita in 2012, which almost tripled. The wage income from migrant labor increased from 2115 (2999-884) to 2925 (5444-2519) yuan per capita from 2008 to 2012, which is comparably much less impressive.

Local off-farm employment is increasing with the prevalence of industrial pollution, while the relationship between total offfarm employment and the prevalence of industrial pollution is not clear. To demonstrate that villages affected by different intensities of industrial pollution tended to be in different stages of off-farm employment, we divided the samples into pollution terciles (zero, low, median, and high intensity of pollution subgroups). Table 2 also shows that for local off-farm employment, not only the annual employment time but also the annual wage income increased with the intensity of industrial pollution, both in 2008 and 2012. A different story emerges when it comes to total off-farm employment in which the migrant labor is included. For total off-farm employment, both the annual employment time and annual wage income do not consistently connect with the intensity of industrial pollution.

Data on village enterprises shed more light on the contribution of village enterprises to local employment opportunities. Of all the 158 enterprises in the village reported by village leaders, about $81 \%$ were polluting, according to the report of the sampling households. We did not exclude the $19 \%$ enterprises not mentioned by households because those enterprises could also be polluting although the pollution is not perceived by the sampling households due to the non-uniform distribution of the pollution source. In fact, the characters of those enterprises are much similar to those enterprises being reported by households, based on a comparison of the nature (by the descriptive information) of these enterprises.

Table 2

The amount of off-farm employment time, wage income from wage earners, and industrial pollution incidence in rural China in 2008 and 2012.

\begin{tabular}{|c|c|c|c|c|c|}
\hline & \multirow[t]{2}{*}{ Sample } & \multicolumn{2}{|c|}{$\begin{array}{l}\text { Annual per capita off-farm } \\
\text { employment time (day) }\end{array}$} & \multicolumn{2}{|c|}{$\begin{array}{l}\text { Annual per capita wage income } \\
\text { (yuan) }\end{array}$} \\
\hline & & Local & Total & Local & Total \\
\hline \multicolumn{6}{|c|}{ Industrial pollution incidence (\%) } \\
\hline \multicolumn{6}{|c|}{2008} \\
\hline Average & 101 & 32.4 & 80.1 & 884 & 2999 \\
\hline 0 & 41 & 23.2 & 73.3 & 520 & 2746 \\
\hline$(0,10]$ & 30 & 31.4 & 75.1 & 1108 & 3203 \\
\hline$(10,25]$ & 29 & 42.9 & 99.2 & 1142 & 3525 \\
\hline$(25,100]$ & 11 & 51.1 & 86.1 & 1215 & 2547 \\
\hline \multicolumn{6}{|l|}{2012} \\
\hline Average & 101 & 45.7 & 83.4 & 2519 & 5444 \\
\hline 0 & 27 & 36.6 & 75.1 & 2157 & 5750 \\
\hline$(0,10]$ & 25 & 44.6 & 86.5 & 2450 & 5280 \\
\hline$(10,25]$ & 13 & 49.0 & 87.0 & 2859 & 5472 \\
\hline$(25,100]$ & 26 & 57.9 & 90.3 & 2928 & 5153 \\
\hline
\end{tabular}

Note: Wage income variables were put into real 2008 yuan terms using the Consumer Price Index from the China Statistical Yearbook (China National Statistical Bureau, 2013).

Source: Authors' 2008 and 2012 survey. 
Table 3

The average employees and the percent of employees from sampling villages of the enterprises within sampling villages and the enterprises outside of the village and polluted the village in China in 2012.

\begin{tabular}{|c|c|c|c|}
\hline & Sample & Average employees (person) & $\begin{array}{l}\text { Percent of employees from } \\
\text { sampling villages (\%) }\end{array}$ \\
\hline \multicolumn{4}{|l|}{ Enterprises within the village } \\
\hline Total & 158 & 49 & 0.31 \\
\hline \multicolumn{4}{|l|}{ The number of employees } \\
\hline$\leq 20$ & 78 & 9 & 0.63 \\
\hline $20-100$ & 64 & 37 & 0.59 \\
\hline$>100$ & 16 & 293 & 0.12 \\
\hline \multicolumn{4}{|l|}{ Enterprises type } \\
\hline Non-pollution intensive factory & 128 & 39 & 0.42 \\
\hline Pollution intensive factory & 30 & 92 & 0.10 \\
\hline \multicolumn{4}{|c|}{ Enterprises outside of the village and polluted the village } \\
\hline Total & 17 & 896 & 0.003 \\
\hline \multicolumn{4}{|l|}{ Enterprises type } \\
\hline Non-pollution intensive factory & 2 & 38 & 0 \\
\hline Pollution intensive factory & 15 & 1010 & 0.003 \\
\hline
\end{tabular}

Source: Authors' 2012 survey.

The local off-farm employment directly provided by the village enterprises is limited, especially for large-scale and pollutionintensive enterprises. First, the off-farm employees engaged in the 158 enterprises only accounted for $1.7 \%$ of the total village population. Second, most of the employees are come from outside of the village. Table 3 shows that, for all of the 158 enterprises, employees from local villages accounted for $31 \%$ of the total, which means most of employees are from outside of the villages. Further breakdown shows that the percentage of employees from local village tends to be much lower especially in large-scale (more than 100 employees) or pollution-intensive enterprises.

Large polluting enterprises outside of the village made very little contribution to employment of local villages. As Table 3 shows, 17 polluting enterprises outside of the village's administrative region were reported according to the respondents in the sampling villages. Most of these enterprises are large-scale pollution-intensive enterprises in mining and chemical industry and accounted for nearly $90 \%$ of the total. Those enterprises usually caused pollution in large scale and hardly made any contribution to the employment of the sampling villages, as the percentage of village employees on total employees is almost negligible.

\section{Econometric models}

The following empirical model is estimated:

$$
Y_{i t}=\alpha+\beta_{1} O_{i t}+\beta_{2} O_{i t}^{2}+\gamma D_{t}+g\left(X_{i t}\right)+\varepsilon_{i t}
$$

where $i$ references a village and $t$ represents the $t$ th year, 2008 or 2012. The dependent variable Yit is a continuous variable between 0 and 100, representing industrial pollution incidence among 20 sampling households in each village.

The main explanatory variable of interest is $O_{i t}$, which is off-farm employment level of the village, measured by local or total (including local and migrant) annual average off-farm employment time (day), or annual average off-farm wage income (thousand yuan) of all the population ${ }^{5}$ in the 20 sample households in the village. We are interested in the coefficients $\beta_{1}$ and $\beta_{2}$, which capture the relationship between off-farm employment level and industrial pollution. When $O_{i t}$ is measured by local offfarm employment level, we anticipate $\beta_{1}$ to be a positive coefficient, indicating that industrial pollution increases with local off-farm employment level at first, and $\beta_{2}$ to be a negative coefficient, indicating that industrial pollution finally becomes less severe as local off-farm employment level rises. However, if $O_{i t}$ is measured by total off-farm employment level, we anticipate that $\beta_{1}$ and $\beta_{2}$ would be less significant. $D_{t}$ is a dummy variable, which equals one in 2012 and zero in 2008. $X_{i t}$ is a vector of the observable characteristics of the village that might influence industrial pollution incidence, which include the following: (1) population density (person/ha), which is the village population divided by the village land area (the land area is calculated as the sum of the land size of community area, planting land, woodlands, grasslands, and water surface area); (2) distance to the capital, distance from village to the capital of the province seat $(\mathrm{km})$; (3) distance to the township, distance from village committee to township seat $(\mathrm{km})$; and (4) dummy variables for provinces, which includes four of five provincial dummy variables. The error term is denoted by $\varepsilon_{i t}$. The summary statistics of all variables used in regression are summarized in the Appendix. In the remainder of the article, no matter what estimation approach is used, we construct our data sets consistently. The number of observations will be consistent also, which is a set of two-year panel data of 101 villages.

According to nature of the way that our variables are created, we use the following estimation methods. In our first approach, we assume that the independent variables in the model affect the dependent variable in a linear way. When doing so, we can

\footnotetext{
${ }^{5}$ We did not define it as the average time or income of the off-farm labor force because of the following reasons: labor force or "working-age persons" is hard to define in rural China than in many rural areas; old males over 70 years old are still engaged in working. And more importantly, the size of labor force is not an exogenous variable as it might be vary according to village characters, for example, the size of voluntary unemployment may be decreased by local industrialization.
} 
estimate the equations with ordinary least squares (OLS), using a set of pooled data with both 2000 and 2008 . To better control for the characteristics of each province in the OLS model estimations, we also include province dummy variables. Our first set of OLS estimates of the coefficients will be displayed in Table 4 (columns 1, 3, 5, and 7).

We also use fixed-effects Tobit estimation as our second approach. We use Tobit estimator since the dependent variable is a continuous variable between 0 and 100. Furthermore, we include a set of fixed effects (FE) in the Tobit models since we are concerned about the effects of village unobservable characters, and also the systematic bias from the perception of pollution. When doing so, all non-time varying unobserved effects that affect the intensity of industrial pollution are controlled for. Our second set of estimates of the coefficients will be displayed in Table 4 (columns 2, 4, 6, and 8).

\section{Results and discussions}

In general, the multivariate regressions for almost all the models perform well; the results are summarized in Table A1.

Industrial pollution incidence is found to be positively related with the level of local off-farm employment. The estimation results suggest that there is a positive relationship between industrial pollution incidence and the level of local off-farm employment time. The level of local off-farm employment is significant in model 1, model 3, and model 4 . There is a weak inverted-U relationship between industrial pollution incidence and the level of local off-farm wage income, as the square of local off-farm employment is significant in model 3, which is consistent with the EKC theories that supposed in many studies.

As for the estimation of the level of total off-farm employment, in which migrant labor is included, the relationship is not positive significant. In contrast to the case of local off-farm employment, total off-farm employment is not significant in models 5, 7, and 8 , and even negative significant in model 6 . The seemly confusing results might be explained as areas that less economically benefited from industrialization tent to have more labors migrated out (statistical correlation tests of local off-farm employment time and migrant off-farm employment time found a correlation coefficient of -0.1611 ). Furthermore, the average annual wage income of one migrant labor, which is 10.5 and 20.7 thousand yuan in 2008 and 2012, respectively, is much higher than that of local off-farm labor, which is 5.0 and 12.7 thousand yuan, respectively. When migrant income was included, total off-farm income of less-industrialized areas would not significantly lower than that of industrialized areas.

The regression results also indicate that the incidence of industrial pollution increased from 2008 to 2012 . The dummy variable of $D_{t}$ is significant at $1 \%$ level of significance in most of the models in Table 4, which suggests that the incidence of industrial pollution in 2012 was higher than in 2008.

Table 4

Tobit estimates of industrial pollution incidents.

\begin{tabular}{|c|c|c|c|c|c|c|c|c|}
\hline & \multicolumn{2}{|c|}{$\begin{array}{l}\text { Local employment } \\
\text { time (day) }\end{array}$} & \multicolumn{2}{|c|}{$\begin{array}{l}\text { Local wage income } \\
\text { (thousand yuan) }\end{array}$} & \multicolumn{2}{|c|}{$\begin{array}{l}\text { Total employment } \\
\text { time (day) }\end{array}$} & \multicolumn{2}{|c|}{$\begin{array}{l}\text { Total wage income } \\
\text { (thousand yuan) }\end{array}$} \\
\hline & $(1)$ & $(2)$ & (3) & $(4)$ & (5) & (6) & (7) & (8) \\
\hline & Pooled & $\mathrm{FE}$ & Pooled & $\mathrm{FE}$ & Pooled & $\mathrm{FE}$ & Pooled & $\mathrm{FE}$ \\
\hline Off-farm employment level & $\begin{array}{l}0.552^{* *} \\
(0.234)\end{array}$ & $\begin{array}{c}0.106 \\
(0.235)\end{array}$ & $\begin{array}{l}14.92^{* * * *} \\
(4.097)\end{array}$ & $\begin{array}{l}6.225^{*} \\
(3.238)\end{array}$ & $\begin{array}{l}-0.324 \\
(0.308)\end{array}$ & $\begin{array}{c}-0.670^{* *} \\
(0.293)\end{array}$ & $\begin{array}{c}4.129 \\
(2.881)\end{array}$ & $\begin{array}{l}-1.044 \\
(2.430)\end{array}$ \\
\hline Square of off-farm employment level & $\begin{array}{l}-0.00120 \\
(0.00184)\end{array}$ & $\begin{array}{c}0.00245 \\
(0.00175)\end{array}$ & $\begin{array}{l}-1.455^{* *} \\
(0.568)\end{array}$ & $\begin{array}{l}-0.498 \\
(0.372)\end{array}$ & $\begin{array}{l}0.00309^{*} \\
(0.00164)\end{array}$ & $\begin{array}{l}0.00312^{*} \\
(0.00159)\end{array}$ & $\begin{array}{l}-0.253 \\
(0.209)\end{array}$ & $\begin{array}{c}-0.0748 \\
(0.137)\end{array}$ \\
\hline Year $(0=2008,1=2012)$ & $\begin{array}{c}2.448 \\
(3.966)\end{array}$ & $\begin{array}{l}5.920^{* *} \\
(2.672)\end{array}$ & $\begin{array}{l}-5.496 \\
(5.083)\end{array}$ & $\begin{array}{l}3.564 \\
(3.873)\end{array}$ & $\begin{array}{l}8.173^{* *} \\
(3.870)\end{array}$ & $\begin{array}{l}11.30^{* * *} \\
(2.087)\end{array}$ & $\begin{array}{c}4.346 \\
(5.006)\end{array}$ & $\begin{array}{l}14.79^{* * *} \\
(4.097)\end{array}$ \\
\hline $\ln ($ population density (person/ha)) & $\begin{array}{l}5.675^{* *} \\
(2.539)\end{array}$ & $\begin{array}{l}12.69^{* * *} \\
(4.232)\end{array}$ & $\begin{array}{l}5.926^{* *} \\
(2.614)\end{array}$ & $\begin{array}{l}11.67^{* * *} \\
(4.318)\end{array}$ & $\begin{array}{l}6.965^{* * *} \\
(2.662)\end{array}$ & $\begin{array}{l}11.37^{* * * *} \\
(4.308)\end{array}$ & $\begin{array}{l}6.411^{* *} \\
(2.714)\end{array}$ & $\begin{array}{l}10.33^{* *} \\
(4.343)\end{array}$ \\
\hline Distance from village to the capital of the province seat $(\mathrm{km})$ & $\begin{array}{l}-0.00778 \\
(0.0191)\end{array}$ & & $\begin{array}{l}-0.0193 \\
(0.0199)\end{array}$ & & $\begin{array}{l}-0.0115 \\
(0.0200)\end{array}$ & & $\begin{array}{c}-0.0296 \\
(0.0201)\end{array}$ & \\
\hline Distance from village committee to township seat (km) & $\begin{array}{l}-0.332 \\
(0.447)\end{array}$ & & $\begin{array}{l}-0.594 \\
(0.454)\end{array}$ & & $\begin{array}{l}-0.403 \\
(0.486)\end{array}$ & & $\begin{array}{l}-0.704 \\
(0.494)\end{array}$ & \\
\hline Jiangsu & $\begin{array}{l}15.87^{* *} \\
(6.574)\end{array}$ & & $\begin{array}{l}11.52^{*} \\
(6.798)\end{array}$ & & $\begin{array}{l}13.72^{* *} \\
(6.886)\end{array}$ & & $\begin{array}{l}5.735 \\
(6.934)\end{array}$ & \\
\hline Sichuan & $\begin{array}{c}27.88^{* * * *} \\
(6.469)\end{array}$ & & $\begin{array}{c}24.89^{* * * *} \\
(6.787)\end{array}$ & & $\begin{array}{c}27.84^{* * * *} \\
(6.950)\end{array}$ & & $\begin{array}{c}20.55^{* * * *} \\
(7.321)\end{array}$ & \\
\hline Shanxi & $\begin{array}{l}13.67^{*} \\
(7.046)\end{array}$ & & $\begin{array}{c}10.97 \\
(7.548)\end{array}$ & & $\begin{array}{c}10.05 \\
(7.431)\end{array}$ & & $\begin{array}{c}1.734 \\
(7.503)\end{array}$ & \\
\hline Jilin & $\begin{array}{l}15.80^{* *} \\
(6.183)\end{array}$ & & $\begin{array}{l}15.09^{* *} \\
(6.586)\end{array}$ & & $\begin{array}{l}19.54^{* * * *} \\
(6.923)\end{array}$ & & $\begin{array}{l}12.99^{*} \\
(7.471)\end{array}$ & \\
\hline LR $\chi^{2}$ & 58.38 & 312.9 & 52.03 & 305.19 & 47.42 & 306.79 & 38.05 & 307.2 \\
\hline Prob $>\chi^{2}$ & 0.000 & 0.000 & 0.000 & 0.000 & 0.000 & 0.000 & 0.000 & 0.000 \\
\hline Pseudo $R^{2}$ & 0.04 & 0.24 & 0.04 & 0.23 & 0.04 & 0.23 & 0.03 & 0.23 \\
\hline
\end{tabular}

Note: Robust standard errors in parentheses. The sample size is 202. Total employment time or total wage income defined as the employment time or wage income from both local and migrant.

Source: Authors' estimation based on the surveyed data.

* Statistical significance at the $10 \%$ level.

** Statistical significance at the 5\% level.

*** Statistical significance at the $1 \%$ level. 
Population density is also found to have statistically significant and positive coefficient on industrial pollution incidence, which is in agreement with the prior studies (Lu \& Zhong, 2009; Schoolman \& Ma, 2012). Population density is significant in all of the models in Table 4. In areas with high population density, the availability of labor force usually attracted more factories to operate in the area, which resulted in high incidence of industrial pollution. Furthermore, the ratio of households that perceive industrial pollution might be higher in high population density areas than in low population density areas, after controlling for the level of pollution.

Geographic characteristics of the village do not have any impact on the incidence of industrial pollution. No matter what estimation method is used, it is consistently observed that neither the distance to capital of the province nor the distance to the township seat has any significant impact on the incidence of industrial pollution incident. Our findings do not in agreement with the Duvivier and Xiong (2013) that location or geography matters contribute toward environmental inequality, basing on a study of polluting firms' location choices in Hebei province.

Finally, the results show most of the province dummy variables have significant impacts on the intensity of industrial pollution. Villages in Hebei, the omitted province, enjoy lower intensity of industrial pollution, the reported perception of pollution tends to be lower there than in other provinces, often significantly. It is interesting to find that in contrast to the common view that costal or more developed areas suffered more from industrial pollution (Lu \& Zhong, 2009), rural areas in inland provinces as Sichuan and Jilin tend to be suffered more from industrial pollution in China.

\section{Conclusion}

The economic gains associated with industrialization in rural China have however come at an environmental, health, and social costs. Yet while it is widely accepted that industrialization has brought both environmental pollution and economic growth in rural areas of China, very little is known about whether the negative effects of industrial pollution on rural residents have been proportionally offset by positive effects due to improvements in off-farm income. Furthermore, in the context of China's migration phenomenon, the relationship between industrial pollution and level of total off-farm income is more confusing.

This paper improves our understanding of these tradeoffs by conducting an empirical analysis based on a set of nationwide panel data collected in 2008 and 2012. It focuses on rural residents who, compared to their urban counterparts, have historically been treated the low status group in China and tend to be more adversely affected by the process of industrialization of China. As far as we know, our nationally representative data are unique and representative. Compared to the prior studies, such as case study or analysis within one province, our survey randomly selected five sample provinces from each of China's major agroecological zones. In total, five provinces, 25 counties, 50 towns, 101 villages, and 2020 households were included in the survey.

Empirical analysis shows that industrial pollution is revealed to be on the rise in rural China. Specifically, the proportion of rural households affected by industrial pollution was 10.7\% in 2008 and this figure increased to 17.9\% in 2012. Both pollution from pollution intensive and non-pollution intensive industry increased between 2008 and 2012. At the same time, off-farm employment became a more important means for rural residents to diversify their income in China, as annual per capita offfarm wage income increased from 2999 to 5444 yuan between 2008 and 2011.

Evidence is found to suggest that it is not always the case that rural households that are affected by pollution reap the offfarm employment benefits associated with industrialization. Rural households enjoy economic benefits from industrialization both in local and urban areas, while rural environment is only associated with local industry. Although industrial pollution incidence is found to be positively related with the level of local off-farm employment, this relationship is statistically insignificant when migrant labor is included. Local off-farm employment directly provided by the local enterprises is limited, especially for large-scale and pollution-intensive enterprises. Areas that less economically benefited from industrialization tent to have more labors migrated out and the average annual wage income of one migrant labor is much higher than that of local offfarm labor.

Industrial pollution incidence is higher in areas with high population density in rural China, which is in agreement with the prior studies. But our findings do not in agreement with the prior studies that location or geography matters, for example, the distance from village to capital of the province or township seat, contribute toward environmental inequality. Rural areas in inland provinces as Sichuan and Jilin tend to be suffered more from industrial pollution in China when other variables are controlled.

Overall, the analysis illustrates that the balance between economic growth and environmental goals is not easy to strike and thus all levels of government are recommended to regularly identify and address the tradeoffs in a comprehensive way. The degradation of rural environment is always lack of attention, as central government always attaches more importance to urban areas. The environmental regulations enforced in rural areas should be more stringent. Under the background of increasing migrations in China, the goal of central government should pay more attention to environmental equality in China. Polluting industry should be avoided to concentrate on areas with high population densities, where the availability of labor force usually attracted more factories to operate in the area and consequently resulted in high incidence of industrial pollution.

Moreover, the goal of local government might switch from an old theme of highlighting local industrialization or economic development to a helicopter view of pursuing a better life quality for the residents, concerning economy growth and environmental sustainability, for both current and future. Except for the tax revenue contribution to local government, the local off-farm employment directly provided by local enterprises is limited. Large polluting enterprises, for example, mining and chemical industry, usually caused pollution in large scale and hardly made any contribution to the employment of the local residents. If 
we have enough samples, we could like to target our analysis at specific rural areas in the future. In addition, more specific countermeasures could be put forward if more information about pollution enterprises could be available.

\section{Acknowledgments}

This research is supported by the National Natural Sciences Foundation of China (grant nos. 71103013, 71033003, 71203235). The authors thank Prof. Zhang Linxiu and other staffs and students, Center for Chinese Agricultural Policy, Chinese Academy of Sciences, for their help and support.

\section{Appendix A}

Table A1

Summary statistics of all variables used in the econometric analysis.

\begin{tabular}{|c|c|c|c|c|}
\hline Variables & Mean & SD & Min & Max \\
\hline Incidence of industrial pollution (\%) & 14.3 & 20.3 & 0 & 95 \\
\hline Annual per capita off-farm employment time of local (day) & 39.0 & 27.3 & 0.6 & 149.4 \\
\hline Annual per capita off-farm employment time of local and migrant (day) & 81.7 & 30.2 & 20.8 & 183.8 \\
\hline Annual per capita wage income of local (thousand yuan) & 1.7 & 1.6 & 0.0 & 7.9 \\
\hline Annual per capita wage income of local and migrant (thousand yuan) & 4.2 & 2.7 & 0.8 & 21.6 \\
\hline Dummy variable of year $(0=2008,1=2012)$ & 0.5 & 0.5 & 0 & 1 \\
\hline Population density (ha/person) & 12.1 & 38.9 & 0.5 & 512.7 \\
\hline Distance from village to the capital of the province seat $(\mathrm{km})$ & 238 & 109 & 23 & 454 \\
\hline Distance from village to the township seat $(\mathrm{km})$ & 5.7 & 4.7 & 0.0 & 22.5 \\
\hline
\end{tabular}

Note: the sample size is 202.

Source: Authors' survey in 2008 and 2012.

\section{References}

Apelberg, B.J., Buckley, T.J., \& White, R.H. (2005). Socioeconomic and racial disparities in cancer risk from air toxics in Maryland. Environmental Health Perspectives, 113(06), 693-699.

Brajer, V., Mead, R.W., \& Xiao, F. (2010). Adjusting Chinese income inequality for environmental equity. Environment and Development Economics, 15(3), $341-362$.

Brajer, V., Mead, R.W., \& Xiao, F. (2011). Searching for an environmental Kuznets curve in China's air pollution. China Economic Review, $22(3), 383-397$.

China rural statistical yearbook. (2013).China statistics press.

Diao, X.D., Zeng, S.X., Tam, C.M., \& Tam, V. (2009). EKC analysis for studying economic growth and environmental quality: A case study in China. Journal of Cleaner Production, 17(5), 541-548.

Downey, L. (2006). Using geographic information systems to reconceptualize spatial relationships and ecological context. American Journal of Sociology, 112(2), 567-612.

Du, L.M., Wei, C., \& Cai, S.H. (2012). Economic development and carbon dioxide emissions in China: Provincial panel data analysis. China Economic Review, 23(2), $371-384$.

Dunlap, R.E., \& Mertig, A.G. (1997). Global environmental concern: An anomaly for postmaterialism. Social Science Quarterly, 78(1), 23-29.

Duvivier, C., \& Xiong, H. (2013). Transboundary pollution in China: A study of polluting firms' location choices in Hebei province. Environment and Development Economics, 18(4), 459-483.

Ebenstein, A. (2012). The consequences of industrialization: Evidence from water pollution and digestive cancers in China. The Review of Economics and Statistics, 94(1), $186-201$.

Edmonds, R.L. (1998). Studies on China's environment. The China Quarterly, 156, 725-732.

Engardio, P. (2009). Cradle of a green revolution. Business Week, 4153, 40-41.

Fang, H., \& Rizzo, J.A. (2011). Income inequality dynamics in rural China from 1991 to 2006: The role of alternative income sources. Applied Economics Letters, 18(14), 1307-1310.

Henri, L.F.M., Cees, A.W., \& Zhou, M.L. (2004). Dynamics of China's regional development and pollution: An investigation into the environmental Kuznets curve. Environment and Development Economics, 9(4), 507-537.

Jalil, A., \& Mahmud, S.F. (2009). Environment Kuznets curve for CO2 emissions: A cointegration analysis for China. Energy Policy, 37(12), 5167-5172.

Jia, X., Xiang, C., \& Huang, J. (2013). Microfinance, self-employment, and entrepreneurs in less developed areas of rural China. China Economic Review, 27(4), 94-103.

Khan, A.R., Griffin, K., Riskin, C., \& Zhao, R. (1992). Household income and its distribution in China. The China Quarterly, 32(132), 1029-1061.

Knight, J., Deng, Q., \& Li, S. (2011). The puzzle of migrant labour shortage and rural labour surplus in China. China Economic Review, 22(4), 585-600.

Liu, X., Heilig, G., Chen, J., \& Heino, M. (2007). Interactions between economic growth and environmental quality in Shenzhen. Ecological Economics, 62(3-4), $559-570$.

Lu, C., \& Zhong, X. (2009). Spatial and temporal patterns of cancer villages in China. Modern Agricultural Sciences, 16, $243-244$.

Ma, C.B. (2010). Who bears the environmental burden in China: An analysis of the distribution of industrial pollution sources? Ecological Economics, 69(9), 1869-1876.

Ministry of Environmental Protection, MEP (1995). Annual statistic report on environment in China. 
Mohai, P., \& Saha, R. (2006). Reassessing racial and socioeconomic disparities in environmental justice research. Demography, 43(2), 383-399.

National Bureau of Statistics of the People's Republic of China (NBSPRC) (2014C). China development report. China statistics press.

Rizwanul, I., \& Jin, H. (1994). Rural industrialization: An engine of prosperity in postreform rural China. World Development, $22(11)$, $1643-1662$.

Schoolman, E.D., \& Ma, C. (2012). Migration, class and environmental inequality: Exposure to pollution in China's Jiangsu province. Ecological Economics, 75 , $140-151$.

Shen, J.Y. (2006). A simultaneous estimation of environmental Kuznets curve: Evidence from China. China Economic Review, 17(4), 383-394.

Song, T., Zheng, T., \& Tong, L. (2008). An empirical test of the environmental Kuznets curve in China: A panel cointegration approach. China Economic Review, 19(3), 381-392.

Su, Y., \& Ma, Z.Z. (2006). Research on China's rural environmental pollution problems and corresponding countermeasures in rural modernizing process. China Population, Resources and Environment, 16(2), 12-18.

Swanson, K.E., Kuhn, R.G., \& Xu, W. (2001). Environmental policy implementation in rural China: A case study of Yuhang, Zhejiang. Environmental Management, 27(4), 481-491.

Tang, S.L., Meng, Q.Y., Chen, L., Bekedam, H., Evans, T., \& Whitehead, M. (2008). Tackling the challenges to health equity in China. The Lancet, 372(9648), $1493-1501$.

Tilt, B. (2006). Perceptions of risk from industrial pollution: A comparison of occupational groups. Human Organization, 65(2), $115-127$.

Tilt, B. (2007). The political ecology of pollution enforcement in China: A case from Sichuan's rural industrial sector. The China Quarterly, 192, 915-932.

Wang, M., Webber, M., Finlayson, B., \& Barnett, J. (2008). Rural industries and water pollution in China. Journal of Environmental Management, 86(4), 648-659.

Wang, X., Huang, J., Zhang, L., \& Rozelle, S. (2011). The rise of migration and the fall of self employment in rural China's labor market. China Economic Review, 22(4), $573-584$.

Wang, Z.H. (2006). Subjective causes and countermeasures on the pollution of township enterprises. Science-Technology and Management, 6, 1-4.

Wang, Z.X., Smyth, R., \& NG, Y.K. (2009). A new ordered family of Lorenz curves with an application to measuring income inequality and poverty in rural China. China Economic Review, 20(2), 218-235.

World Bank (2007). Cost of pollution in China: Economic assessment of physical damage. Washington, DC: The World Bank.

Yang, J., Yang, Z.K., \& Sheng, P.F. (2011). Income distribution, human capital and environmental quality: Empirical study in China. Energy Procedia, 5(22), $1689-1696$.

Zhang, J., Mauzerall, D.L., Zhu, T., Liang, S., Ezzati, M., \& Remais, J.V. (2010). Environmental health in China: Progress towards clean air and safe water. Lancet, 375(9720), 1110-1119. 